in irradiated bones six to twenty-two years after radiation. Radiation is a form of injury and undoubtedly it may precipitate malignant change in a bone. But it is only fair to point out that the dosage in experimental cases, and others in which malignant change occurred, was far in excess of the 2000 roentgen which is the dosage now used in treating giant-cell tumours. Nevertheless the warning should be accepted. The cure of giant-cell tumours by $\mathrm{X}$-ray therapy should be achieved by moderate doses and the possibility that larger doses may give rise to sarcoma should always be in mind.

The occurrence of giant-cell tumours in association with Paget's disease, as recorded by Professor Russell, is of great interest by reason of its rarity. Has it ever been recorded before? It is also of interest because of the similarity between the bone changes of osteitis deformans and osteitis fibrosa, and the possible relationship between osteitis fibrosa and osteoclastoma.

STANFoRd CADE.

\title{
TRAVELLING FELLOWS IN ORTHOPAEDIC SURGERY FROM THE AMERICAN GONTINENT-THE A.B.C. CLUB
}

The first cycle of a new adventure has been completed. Last year, thirteen young British orthopaedic surgeons were guests of American and Canadian hosts; they visited important orthopaedic centres in the North American continent and attended the historic combined meeting of the American, Canadian and British Orthopaedic Associations in Quebec. This year, ten American and five Canadian orthopaedic surgeons were guests of British hosts; they visited orthopaedic centres in this country and made important contributions to the Spring meeting of the British Orthopaedic Association in Nottingham.

The travellers were met on board the "Queen Mary" at Southampton by the President, ex-President, Treasurer and other Officers of the British Orthopaedic Association; and having made short shrift of Customs, and the problem of finding taxicabs at Waterloo, the memory that remains is that of the calm serenity of Big Ben and the Houses of Parliament, silhouetted in a moonlit sky. The smooth-moving waters of the Thames, almost within reach of Pinafore Room of the Savoy Hotel where the official dinner of welcome was attended by nearly every London orthopaedic surgeon, promised the peace and calm which surely was to be needed in a hectic journey from London to Cambridge, Luton, Norwich and Newcastle; Edinburgh and Glasgow to Loch Lomond and the English Lakes; Liverpool, Manchester, Oswestry and Birmingham to Stratford-upon-Avon, Nottingham and the Sherwood Forest; Derby, Oxford, Bath, Bristol and Exeter to Stoke Poges, Windsor and the Golden Valley.

The travellers were driven many hundreds of miles, at a very safe pace, by the reliable Irishman Pat, in the unheated omnibus which soon became known as the Deep Freeze. It lacked in calories but not in confidence. Still held in secret are the vivid and uninhibited impressions of American and Canadian members of the A.B.C. club-the club of American, British and Canadian Travelling Fellows in Orthopaedic Surgery, established formally in Nottingham with only one rule-that every member would play his part in facilitating the visits of young orthopaedic surgeons from one country to the other. A conception so warm in its ideals should not have been conceived in an environment so cold. Our southern American visitors believe that bilateral cervical and lumbar sympathectomy is needed if Britain is to be appreciated. Cambridge, the first halt on their journey, is still replenishing its stocks of full arm and leg length woollen underwear!

Ham Allan of Philadelphia fulfilled the rôle of leader with unfailing charm and competence and showed great skill in the delegation of responsibility. Ted Dewar of Toronto was adjutant, and we are sorry that there was not time to learn more of his remarkable knowledge of scoliosis. Don Blanche from Los Angeles thought much but spoke little-and always to the point. Verne Inman of San Francisco won admiration for the fluency of his delivery at Nottingham when one photograph showed his own shoulder girdle bristling with fearsome 
bone-transfixion pins. John Fahey of Chicago heard everything, saw everything, and was ready to discuss everything; he received many cablegrams reporting yet further additions to his family and at one time it appeared that he might even be the parent of quintuplets; but with undisturbed equanimity he left, as he arrived, the proud parent of a single child that he has not yet seen. Benny Obletz of New York did not, as we had been warned, " take or talk the nerves out of every hip joint "; he was objective and modest in his claims. Carroll Larson of Boston distinguished himself not only by modesty but by making the best speech of all that were delivered at the Annual dinner of the Association and by arriving on board the last day, unshaven and unslept, happy in having advised on arthroplastv. Bill Bickel of the Mayo Clinic shamed us by his knowledge of E, A, F, DCA and ACTH and by his ability as a woodsman; he can indeed handle an axe. Leo Walker of Montreal sustained the Canadian reputation for skilful colour cinematography with Mickey Mouse interpolations. Hugh Smith of Memphis played nearly every piano in Britain; with the cover of a keyboard he nearly amputated the fingers of the Editor of this Journal; and he was the first American to hold up a British express train. Frank Paterson of Vancouver represented the Western Canadian seaboard and spoke well for his colleagues at the Robert Jones and Agnes Hunt Orthopaedic Hospital. Bill McKinnon of Winnipeg, who knew us during the war, still speaks fluently in public while remaining modest and reserved in private conversation. Ramsey Straub of New York will be remembered for his careful presentation of the problems of lumbo-sacral fusion; but we cannot forget the tug "Romsey" of immense girth and power that moved the "Queen Mary," and we will always think of him as "Friar Tuck of Sherwood Forest." Ben Fowler of Nashville was never lacking in wit; when seen handling a rope outside a suite of operating theatres, he replied that British surgeons visiting America had feared that Arbuthnot Lane might turn in his grave, but from what he had just seen a rope was needed to prevent Arbuthnot Lane from rising from his grave.

The last day was spent in the Royal College of Surgeons of England. Professor Wood Jones showed many of the treasures of the Hunterian Museum - the first madder experiments on bone growth, the injected placenta which maintains its colour as if prepared a few days ago, and the wonderfully preserved specimen of a cock's comb with implantation and survival of a human tooth. A densely packed audience witnessed conferment of the Honorary Fellowship of the Royal College of Surgeons of England-a jealously guarded honour-upon Robert Harris of Toronto who, being made a Fellow of the College, was then able as Hunterian Professor to deliver a lecture on the problems of spondylolisthesis. The American and Canadian guests were entertained to dinner in the Library, and on the tables were John Hunter's tankard, Cheselden's cup, Colles's silver, and other personal possessions of the great masters of surgery. The unprecedented wearing by Lord Webb-Johnson, the President of the College, of his tartan waistcoat was matched by the wearing of tartan waistcoats by every single one of the visiting surgeons.

As if the tour had not been exhausting enough the last Sunday was spent at House-in-theWood, where agreement in publication of a joint British-American Journal of Bone and Joint Surgery was reached. Sunday-a day of rest indeed! A walking tour of the estate, the fighting of a forest fire, and the competitive felling of huge timber, was the order of the day. Ted Dewar and Bill Bickel, with their Canadian and Minnesotan backwoodsmanship felled their tree first; Reg Watson-Jones and Scotty Law crashed theirs to the ground thirty seconds later. Dinner was at the Royal Anchor Hotel, Liphook, renowned for the visits of Wellington, Nelson, Churchill, Eisenhower, and Canadian surgeons of Connaught Hospital.

What shall be said of this venture? British orthopaedic surgeons who went to America last year cherish memories of their visit and will do so for the rest of their days. This year, we in Britain have gained inestimable stimulus from the visit of surgeons from the North American continent. We have learned to know each other. Friendships, enduring friendships, have been established. Long may they be encouraged.

H. OSMOND-Clarke.

vol. $31 \mathrm{~B}$, No. 2, MAY 1949 